\title{
PERANAN INVESTASI ASING DALAM PERCEPATAN PERTUMBUHAN EKONOMI DI INDONESIA
}

\author{
OK Isnainul' ${ }^{1}$ Elvira Fitriyani Pakpahan ${ }^{2}$, Michelle Hadlen ${ }^{3}$, Michael $^{4}$, \\ Danniel $^{5}$, Cindy Winni Violita ${ }^{6}$ \\ Fakultas Hukum Universitas Prima Indonesia, Indonesia \\ Email : elvirapakpahan@unprimdn.ac.id
}

\begin{abstract}
ABSTRAK
Peranan investasi asing sangat menentukan laju pertumbuhan perekonomian nasional seperti banyaknya perbaikan infrastruktur dan sarana dan prasarana. Jenis Penelitian yuridis normatif. Sifat penelitian deskriptif, teknik pengumpulan data menggunakan data primer, sekunder dan tersier. Analisis data menggunakan analisis kualitatif. Peranan Investasi asing memberikan kontribusi yang nyata bagi perekonomian, perkembangan teknologi, perbaikan infarstruktur serta menciptakan lapangan pekerjaan dan menghasilkan penerimaan Negara. Kendala yang muncul yakni regulasi berbelit, akuisisi lahan yang sulit, infrastruktur publik yang belum merata, pajak dan insentif nonfiskal lain tidak mendukung investasi dan tenaga kerja terampil yang belum memadai. Upaya menarik investasi asing dalam mempercepat pertumbuhan ekonomi nasional diantaranya Inftrastruktur, tenaga kerja terampil, kemudahan perizinan, insentif dari pemerintah, jaminan hukum dan kesejahteraan masyarakat.
\end{abstract}

Kata Kunci : investasi asing; pertumbuhan ekonomi

\section{ABSTRAK}

The role of foreign investment greatly determines the rate of growth of the national economy such as the many improvements to infrastructure and facilities and infrastructure. Type of research is normative juridical research. The nature of research is descriptive research. Data collection techniques is using primary, secondary and tertiary data. Data analysis uses qualitative analysis. The role of foreign investment makes a real contribution to the economy, technological development, improvement of infrastructure and creates jobs and generates state revenue. Constraints that arise are complicated regulations, difficult land acquisition, uneven public infrastructure, taxes and other non-fiscal incentives do not support inadequate investment and skilled labor. Efforts to attract foreign investment in accelerating national economic growth include infrastructure, skilled labor, ease of licensing, incentives from the government, legal guarantees and public welfare.

\section{Keyword : Foreign investment; economic growth}

\section{A. PENDAHULUAN}

Investasi asing atau penanaman modal asing (PMA) dapat membwa dampak positif terhadap pembangunan sebuah negara Investasi asing datang ke Indonesia membawa sejumlah proyek di Indonesia. ${ }^{1}$ Investasi asing dipengaruhi oleh kemantapan politik, keamanan, SDA, pengalaman kerja, keputusan di bidang ekonomi dan lembaga keuangan secara tervka, maka investasi asing menjadi minat bagi penanam modal yang ingin membangun dan memajukan suatu wilayah di Indonesia. ${ }^{2}$

Adanya investasi asing ke Indonesia sudah tentu pemerintah siap segala sektor dalam mempercepat pertumbuhan. Regulasi terkait investasi asing sudah ada semenjak tahun 1967 setelah itu mengalami perubahan regulasi di tahun 2007 dengan disahkan penanaman modal yang baru Nomor 25 Tahun 2007 tentang Penanaman Modal. Begitu pentingnya regulasi

${ }^{1}$ Salim HS dan Budi Sutrisno, (2008).Hukum Investasi di Indonesia, Jakarta: PT. Rajagrafindo Persada, hlm. 216

${ }^{2}$ Ana Rokhmatussa"dyah dan Suratman.(2015). Hukum Investasi \& Pasar Modal. Jakarta: Sinar Grafika, hlm 115 
investasi asing tersebut dalam langkah mempercepat pertumbuhan ekonomi di Indonesia. Disamping itu juga menstabilkan perekonomian yang ada mengingat perkembangan investasi asing kian meningkat. Sebagaimana tertera dalam perundang-undangan penanaman modal sudah diatur sepenuhnya dalam investasi asing maupun dalam negeri, agar menjaga keutuhan bangsa dan negara dalam memajukan rakyat dan wilayah Indonesia. Landasan hukum kian jelas adanya regulasi terkait investasi asing yang melakukan kegiatan usahanya di wilayah kota/desa di Indonesia. ${ }^{3}$

Pentingnya investasi asing akan meningkatkan roda pertumbuhan perekonomian dan mempercepat pembangunan. Menurut UUPM (Undang-undang Penanaman Modal) merupakan kegiatan sebuah usaha yang dilakukan pemilik modal untuk menciptakan dan mewujudkan pertumbuhan suatu wilayah dan sepenuhnya dana yang diimpun berdasarkan saling berpatungan dalam berinvestasi dalam negeri.

Investasi asing berperan dalam meningkatkan laju pertumbuhan perekonomian nasional misalnya tidak sedikit investasi asing mendirikan perusahaan yang menjadi program pertumbuhan, penyempurnaan sarana dan prasarana. Laju pertumbuhan perekonomian di tahun 2019 mengalami peningkatan tetapi lama kelamaan mampu memenuhi kebutuhan akan modal asing. Modal asing melakukan semua ini karena penduduk memiliki berskala kecil makanya investor menanamkan usahanya cukup berkembang dari pada perkotaan. Memajukan suatu wilayah tergantung sumber daya yang ada, justru dimanfaatkan investasi asing untuk mewujudkan pertumbuhan dan mensejahterakan. Apabila penduduk berskala kecil akan berdampak pendapatan meningkat, akibatnya kehadiran investasi asing yang ditanamkan dalam suatu negara tidak memperoleh keuntungan. ${ }^{4}$

Keuntungan yang diperoleh dalam investasi asing lama kelamaan akan fluktuatif, seiring dengan keadaan pandemi corona dan pertumbuhan ekonomi semakin menurun hal ini disebabkan sumber daya yang dimiliki sedikit, dilihat dari perkembangan penduduk dan tenaga kerja yang ada belum mencukupi. Untuk itu pemerintah harus mengambil langkah/kebijakan yang tegas untuk mengatasi tenaga kerja kian hari meningkat dan pengangguran semakin naik. Oleh karena itu, investasi asing bisa memiliki daya tampung tenaga kerja yang terampil dan skill. $^{5}$

Tenaga kerja yang terampil dan skill akan mudah memperkerjakan perusahaan asing, maka pemerintah mengizinkan investor masuk ke dalam agar terciptanya lapangan kerja, dan perizinan bagi investai asing lebih dipermudah agar perusahaan-perusahaan asing bisa memperkerjakan penduduk indonesia. Sebagaimana regulasi yang dibuat oleh pemerintah sangat mempemudah proses dan prosedur yang ditetapkan bagi investor. Disamping itu, investasi dapat terlindungi dan rasa aman menanamkan modalnya. Izin sudah diatur terkait investasi asing dalam menunjang kegiatan usahanya agar tidak terabaikan. Pemerintah ikut mengantisipasinya dan melindungi investor asing yang membuka segala sektor di Indonesia. Perizinan sebuah payung hukum dalam menjaga dan keamanan dalam berinvestasi asing. Pemerintah sangat memperhatikan dan mewujudkan kehadiran investasi mampu membawa kemajuan dan mengelola dalam mempercepat pertumbuhan perekonomian. Perizinan sangat diperlukan bagi investo asing dalam rangka mempercepat pertumbuhan dan stabilitas ekonomi. Di Indonesia mengharapkan investasi asing mempunyai prinsip dan tujuan yang dicapai. Disamping itu bagi investasi asing sudang terlindungi dari regulasi yang dibuat dan sebagai payung hukum secara baik. Hanya saja pemerintah bisa mengawasi dalam kegiatan

${ }^{3}$ David Kairupan, (2013). Aspek Hukum Penanaman Modal Asing di Indonesia, Jakarta: Kencana, hlm. 3

${ }^{4}$ Amiruddin Ilmar, (2007). Hukum Penanaman Modal di Indonesia, Penerbit Kencana, Jakarta,, hlm 184

${ }^{5}$ P. Eko Prasetyo.(2011). Fundamental Makro Ekonomi. Yogyakarta: Beta Offset, hlm. 99 
usaha mana pun khususnya investasi asing. Agar tidak terjadi penyimpangan kegiatan yang dilakukan oleh investasi asing. ${ }^{6}$

Penyimpangan tersebut diantaranya tidak memiliki izin dan penyelewengan badan hukum perusahaan dan lain sebagainya. Masuknya investasi asing sebagai tananan hukum yang tepat, dari regulasi yang dibuat sudah sesuai dan memenuhi kriteria dan perizinan. Hal ini cukup jelas adanya syarat dan ketentuan hukum yang terkait dengan penanaman modal tidak saling bersamaan, karena landasan hukum yang dibuat sudah keterkaitan dengan maksud dan tujuan suatu kegiatan penanaman modalya kedepannya. ${ }^{7}$ Untuk itu kegiatan investasi asing yang dilakukan, harus menciptakan lapangan pekerjaan dan sebagainya, karena bisa menghasilkan keuntungan yang besar jika memiliki wilayah mengizinkan untuk mempercepat pertumbuhan ekonomi. ${ }^{8}$

Pertumbuhan ekonomi sangat terbantu adanya investor yang menanamkan modalnya untuk menciptakan seluruh aspek bidang tertentu. Kondisi daerah sangat menentukan masuknya keluarnya investasi asing yang ingin menanamkan modalnya segala bidang. Untuk itu pemerintah mengarahkan investornya agar memiliki wilayah yang stategis, agar pertumbuhan merata kesemua wilayah Indonesia. ${ }^{9}$ Upaya pemerintah diprioritaskan dalam mempercepat pertumbuhan ekonomi bangsa Indonesia berupa peningkatan investasi asing dalam negeri agar mengelola kesanggupanya menjaga dan keutuhan SDA dan manusia secara merata, kecuali dalam pertukaran perekonomian secara komprehensif, maka Indonesia mengikutsertakan bermacam-macam kemitraan dengan luar negeri. Pada akhirnya menciptakan iklim investasi yang mendukung, memajukan atau peningkatan, memberikan ketentuan hukum, perlakuan dan ketetapan dalam menjalankan sesuatu kegiatan usaha. Masalah investasi asing sudah diatur dalam UUPM dan mengalami perubahan, karena tidak sesuai dengan kebutuhan perekonomian atau perkembangan kiat meningkat. Oleh karena itu pemerintah sudah membuat regulasi dalam penanaman modal diluar maupun dalam negeri. Agar tidak terjadi ksalahpahaman dan perselisihan dalam investor.

Hal ini tidak perlu terjadi antar perselisihan dalam investor karena sudah ada regulasi pemerintah. Apabila investasi asing masuk ke Indonesia sudah tentu mengatur Undang-undang penanaman modal membuka pintu peluang bagi para investor untuk menanamkan modalnya ke Indonesia. Dengan cara ini memberikan keuntungan bagi Indonesia untuk menerima investor asing ke dalam negeri. Disamping itu, menciptakan lapangan kerja untuk kalangan masyarakat bila investor asing masuk dalam berbagai sektor. Peran pemerintah sangat penting dalam memajukan pertumbuhan ekonomi suatu wilayah dan sekaligus mewujudkan percepatan pembangunan jangka panjang maupun jangka pendek. Untuk itu pemerintah bersikap andil dan bijaksana masuknya investasi asing tanpa perlu mengeluarkan dana bagi pemerintah. Hanya investasi asing yang menanamkan modalnya ke Indonesia demi kemajuan saat ini, tetapi ada sesuatu kendala yang harus diperhatikan berupa investasi menyediakan beraneka produk yang ditawarkan kepada masyarakat, investasi membuka peluang tenaga kerja untuk menghasilkan pendapatan dan daya beli masyarakat. Berdasarkan penjelasan diatas akan membawa pertumbuhan ekonomi masyarakat secara terus-menerus akibat minat masyarakat untuk membeli dan menampung penawaran produk. Di sisi lain semua kegiatan ekonomi yang

${ }^{6}$ Nanda Aisyah, Muhammad Ashri, Nurfaidah Said, Analisis Hukum Kebijakan Daftar Negatif Investasi Berdasarkan Peraturan Presiden Nomor 44 Tahun 2016 Terhadap Pengusaha Ritel Indonesia, Jurnal Nagari Law Review Volume 1 Nomor 2, April 2018

${ }^{7}$ Catherine Vania Suardhana, Perlindungan Hukum Terhadap Penanaman Modal Asing pada Sektor Perkebunan di Indonesia, Jurnal Hukum Prasada, Vol. 6, No. 1, Maret 2019

${ }^{8}$ S. Sembiring, Hukum Investasi Pembahasan Dilengkapi dengan Undang-Undang No. 25 Tahun 2007 Tentang Penanaman Modal. Penerbit Nuansa Aulia, Bandung, hlm 48

${ }^{9}$ Bagian c. Menimbang UU Nomor 25 Tahun 2007 Tentang Penanaman Modal 
ditawarkan akan berdampak pada produk barang dan daya beli masyarakat tersebut. Akan lebih menguntungkan bila produk habis terjual dan permintaan berjalan lancar. ${ }^{10}$

Keadaan saat ini investor asing siap membantu menanamkan modalnya setiap daerah dalam mempercepat pembangunan di segala bidang misalnya sektor industri. Secara alternatif investasi asing dapat menempuh jalur hukum berdasarkan undang-undang yang berlaku dan menanamkan modal nya segala sektor. Terkait kondisi tersebut investasi asing dapat memberikan perlindungan hukum dan kepastian hukum atas dasar hukum yang ditetapkan. Dengan hal tersebut masyarakat dapat membuka peluang untuk aktif tenaga kerja dan skill dalam membantu perkembangan investasi saat ini. ${ }^{11}$ Berdasarkan latar belakang tersebut maka peneliti memberikan rumusan masalah adalah:

a. Bagaimana peran investasi asing terhadap percepatan pertumbuhan ekonomi di Indonesia?

b. Bagaimana kendala yang muncul sehubungan dengan peran investasi asing dalam mempercepat pertumbuhan ekonomi di Indonesia?

c. Bagaimana bentuk perlindungan investasi asing dalam hukum penanaman modal di Indonesia?

\section{B. METODE PENELITIAN}

Jenis penelitian yang digunakan dalam penelitian ini adalah penelitian hukum normatif yang menghasilkan analisis preskriptif. Sumber data yang digunakan dalam penelitian ini berasal dari bahan hukum primer, sekunder dan tersier. Analisis data dilakukan dengan menggunakan analisis kualitatif $^{12}$

\section{PEMBAHASAN}

\section{Investasi Asing dan Pertumbuhan Ekonomi Indonesia}

Investasi asing merupakan salah satu indikator pertumbuhan ekonomi yang berperan dalam mengolah potensi ekonomi Indonesia yang besar menjadi kekuatan ekonomi yang riil. Peningkatan investasi asing di Indonesia menjadi penting dalam hal mempercepat pertumbuhan ekonomi nasional dan perwujudan kedaulatan politik serta ekonomi Indonesia.

Pertumbuhan ekonomi merupakan kondisi perekonomian stabil dan menunjukkan keadaan yang lebih baik selama kurun waktu yang ditetapkan. ${ }^{13}$ Pertumbuhan ekonomi terlihat adanya suatu hasil riil pada perubahan perekonomian daerah dan pusat dalam mewujudkan keberhasilan pembangunan suatu negara. Untuk itu pertumbuhan daerah didukung oleh penanaman modal ataupun bantuan pemerintah agar mempercepat perubahan daerah tersebut. Tanpa bantuan tidak akan berhasil membangun suatu daerah tersebut mesti adanya dorongan atau dukungan secara tepat sasaran. Dana yang dikelola harus memprioritaskan mana yang harus dikeluarkan semestinya. Dalam mempercepat pertumbuhan ekonomi harus ada menanamkan modalnya atau membantu infrastruktur. Untuk itu, Indonesia melihat perkembangan era saat ini begitu majunya pertumbuhan ekonomi dan dukungan penanaman modal asing secara terpadu dan memiliki dana yang besar untuk mempercepat pertumbuhan ekonomi. Sebab itu, sejumlah

\footnotetext{
${ }^{10}$ Johnny W. Situmorang.(2011). Menguak Iklim Investasi Pasca Krisis. Jakarta: Erlangga, hlm 74

${ }^{11}$ Agung Sudjati Winata, Perlindungan Investor Asing dalam Kegiatan Penanaman Modal Asing dan Implikasinya Terhadap Negara, Ajudikasi : Jurnal Ilmu Hukum, Vol. 2 No. 2. Desember 2018

${ }^{12}$ Zainuddin Ali.(2014).Metode Penelitian Hukum. Jakarta: Sinar Grafika, hlm. 107

${ }^{13}$ Windhu Putra, Op.Cit, hlm 41
} 
proyek infrastruktur memperoleh dukungan dana, bukan hanya infrastruktur ekonomi tetapi juga infrastruktur bidang lainnya. ${ }^{14}$

Realisasi investasi asing pada 2015-2019 mengalami kenaikan atau tumbuh sebesar 11,5 persen dibandingkan periode yang sama pada tahun sebelumnya. Kenaikan realisasi PMA terjadi di sektor tersier dengan pertumbuhan sebesar 57,9 persen, sedangkan sektor primer dan sekunder mengalami penurunan dengan pertumbuhan negatif masing-masing sebesar 25,0 persen dan 4,5 persen. Untuk PMDN, kenaikan realisasi didorong oleh pertumbuhan positif yang terjadi di sektor primer dan tersier. Kenaikan tertinggi terjadi di sektor primer dengan pertumbuhan sebesar 35,3 persen, diikuti sektor sekunder yang mengalami pertumbuhan sebesar 31,0 persen dibandingkan dengan periode yang sama pada tahun sebelumnya. Berdasarkan sumbangannya, pada triwulan I tahun 2018, sektor tersier adalah pemberi sumbangan terbesar baik untuk PMA maupun PMDN yaitu masing-masing sebesar 46,8 persen dan 50,6 persen.

Berikut pertumbuhan jumlah investasi asing dapat dilihat tahun 2015-2019 mengalami fluktuatif. Hal ini dapat dilihat tabel dibawah ini.

\section{Tabel 1}

Pertumbuhan Investasi PMA dan PMDN tahun 2015-2019 berdasarkan sektor

\begin{tabular}{|c|c|c|c|c|c|c|c|c|}
\hline \multirow{2}{*}{ Tahun } & \multicolumn{3}{|l|}{ PMA } & \multirow[b]{2}{*}{$\begin{array}{c}\text { Jumlah } \\
\text { (USD } \\
\text { juta) }\end{array}$} & \multicolumn{3}{|l|}{ PMDN } & \multirow[b]{2}{*}{$\begin{array}{r}\text { Jumlah } \\
\text { (Rp } \\
\text { Trili- }\end{array}$} \\
\hline & Primer & Sekunder & Tersier & & Primer & Sekunder & Tersier & \\
\hline 2015 & 6.236 .4 & 11.763 .1 & 11.276 .5 & 29.275 .9 & 16.1 & 89.0 & 73,4 & 179.5 \\
\hline$\frac{2016}{2017}$ & $4.501,9$ & 16.687 .6 & 7.774 .6 & $\frac{28.964 .5}{22.32}$ & 27.7 & 106,8 & 817 & 216,2 \\
\hline$\frac{2011}{2018}$ & $\frac{0.010,1}{69913}$ & $\frac{13.148,4}{130194}$ & $\frac{13.015 .0}{85190}$ & $\frac{32.259 .5}{285296}$ & $\frac{43,0}{165}$ & $\frac{99.2}{590}$ & $\frac{119.6}{806}$ & $\frac{261.4}{156.1}$ \\
\hline 2019 & 1.648 .9 & 3.234 .5 & $2.410,3$ & $7.293,7$ & 12,0 & & 29,5 & $\frac{130.1}{68.8}$ \\
\hline $\begin{array}{c}\text { Pertum- } \\
\text { buhan } \\
\text { (\%) }\end{array}$ & $24,0 \%$ & $4,5 \%$ & $57,9 \%$ & $11,5 \%$ & $35,3 \%$ & $21,3 \%$ & $31,0 \%$ & $11,0 \%$ \\
\hline
\end{tabular}

Sumber : BKPM, diolah

Atas dorongan pengusaha untuk menjalin investor ke luar negeri memberi manfaat bagi masyarakat, agar dapat membantu para pekerja. Disamping itu sektor swasta dan pemerintah ikut memperkuat berbagai sektor yang di investasikan guna memberikan percepatan pembangunan. Penggunaan investasi asing akan meningkatkan laju perkembangan ekonomi secara merata dan memberikan dampak positif bagi msyarakat. ${ }^{15}$

Realisasi invetasi asing khusunya PMA tahun 2015-2019 dibanding periode yang sama tahun sebelumnya mengalami peningkatan dengan pertumbuhan sebesar 11,5 persen. Pertumbuhan negatif terjadi di Kalimantan, Sulawesi, Maluku, dan Papua, sementara wilayah lainnya mengalami pertumbuhan positif. Pertumbuhan positif tertinggi terjadi di Sumatera sebesar 44,1 persen. Secara sumbangan, pada triwulan I tahun 2018 pulau Jawa, Sumatera, dan Sulawesi memberikan sumbangan terbesar yaitu 65,3 persen, 16,3 persen dan 6,1 persen.

Tabel 2

Pertumbuhan investasi PMA tahun 2015-2019 berdasarkan lokasi

\begin{tabular}{|c|c|c|c|c|c|c|c|c|}
\hline Tahun & \multicolumn{7}{|l|}{ Lokasi } & Total \\
\hline 2015 & 3.395 .3 & 173 & 8889 & 2.773 .4 & 498.2 & 32 & 2.414 & 28.6 \\
\hline 2018 & & 4 & 7 & & & & .6829 & \\
\hline 2019 & $5.497,3$ & 16.76 & 1.157 .9 & $2.887,4$ & 3.487 .0 & 440,1 & 2.008, & \\
\hline $\begin{array}{l}\text { Pertumbuhan } \\
(\%)\end{array}$ & 44,1 & 42,1 & 34,3 & 59,5 & 45,1 & 64,1 & 39,9 & 11,5 \\
\hline
\end{tabular}

Sumber : BKM, diolah

Peran investasi asing sebagai pembangunan sarana dan prasarana di suatu wilayah agar pendapatan nasional selalu keadaan stabil, semakin besar investasi asing yang digunakan

\footnotetext{
${ }^{14}$ Aminuddin Ilmar, Op.Cit, hlm 37

${ }^{15}$ M.L,Jhingan. (2010). Ekonomi Pembangunan dan Perencanaan. Edisi pertama. Jakarta: Rajawali Press, hlm. 483
} 
maka suatu negara akan melaju pertumbuhan yang pesat dan meningkatkan pendapatan bruto suatu daerah. Tingkat pendapatan bruto semakin baik apabila kondisi ekonomi selalu sehat dan mengurangi dampak. Hal ini diakibatkan karena keadaan krisis ekonomi yang membuat kebutuhan bahan pokok meningkat. Begitu rendahnya perekonomian di Indonesia disaat krisis yang terjadi maka pemerintah membenahi dan mencari bantuan keluar negeri untuk membantu keadaan tersebut berupa masuknya investasi asing mengalami perubahan yang signifikan. Disamping itu pembiayaan pembangunan bersumber dari dana yang diberikan oleh penanaman modal asing untuk membangun kembali perekonomian tersebut. ${ }^{16}$ Kontribusi pembangunan membawa keuntungan bagi investasi asing di Indonesia, karena membawa arah pencapaian perekonomian. ${ }^{17}$

Berdasarkan lokasi lokasi, realisasi PMDN mengalami pertumbuhan positif sebesar 11,0 persen dibandingkan periode yang sama tahun sebelumnya. Pertumbuhan realisasi PMDN terbesar terjadi di Maluku dengan pertumbuhan sebesar 221,8 persen diikuti Sulawesi sebesar 163,9 persen. Sementara itu, Sumatera, Jawa, Bali dan Nusa Tenggara, dan Papua mengalami penurunan dibandingkan dengan periode yang sama tahun sebelumnya. Berdasarkan kontribusinya, Jawa, Kalimantan, dan Sumatera memberikan sumbangan terbesar pada triwulan I tahun 2018 yaitu 53,3 persen, 20,8 persen dan 13,1 persen.

\section{Tabel 3}

Pertumbuhan investasi PMDN tahun 2015-2019 berdasarkan lokasi

\begin{tabular}{|c|c|c|c|c|c|c|c|c|}
\hline \multirow[t]{2}{*}{ Tahun } & & & & & & & Lokasi & \multirow{2}{*}{ Total } \\
\hline & Sumatera & Jawa & Bali \& & Kalimantan & Sulawesi & Maluku & Papua & \\
\hline 2015 & 22.9 & 66.5 & $\frac{1}{4.4}$ & 28.7 & 3.6 & 1.1 & 0.9 & 128.2 \\
\hline 2016 & 29.6 & 971 & 0.5 & 21.4 & 0,0 & 0.2 & 0.3 & $56: 1$ \\
\hline 2017 & 37.8 & 103,8 & 2.9 & 20.0 & 13,7 & 0.0 & 1,3 & 779.5 \\
\hline 2018 & 39,8 & 126,4 & 2,6 & 33,6 & 13,6 & 0,0 & 0,2 & 216,2 \\
\hline $\begin{array}{r}2019 \\
\text { Pertumbuhan }\end{array}$ & $\begin{array}{l}40,2 \\
30,1\end{array}$ & $\begin{array}{r}100,0 \\
0,4\end{array}$ & 9,0 & $\begin{array}{l}30,2 \\
101,6\end{array}$ & $\begin{array}{r}10,1 \\
163,9\end{array}$ & 221,8 & $\begin{array}{r}1,3 \\
99,0\end{array}$ & $\begin{array}{l}262,4 \\
11,0\end{array}$ \\
\hline$(\%)$ & & & & & & & & \\
\hline
\end{tabular}

Sumber : BKM, diolah

Penyerapan dana-dana yang menganggur (idle funds) akan memberikan manfaat dalam realisasi pembangunan ekonomi, disamping itu perusahaan dan masyarakat menyalurkan dana dalam aktivitas yang lebih tepat dan jelas. Agar tidak salahgunakan dalam pembangunan infrastruktur yang ada. Untuk itu, diperlukan investasi asing dalam membantu sebuah pembangunan dan membantu lapangan kerja bagi masyarakat disekitar wilayah yang di investasikan. Kegiatan usaha yang dilakukan investasi asing tersebut berdampak positif dalam perkembangan perekonomian masyarakat dan meningkatkan keuntungan. Dengan adanya modal yang di salurkan ke suatu wilayah desa/kota akan menghasilkan hasil penerimaan negara. ${ }^{18}$

Sebagaimana mestinya investasi asing dianggap baik dalam menyelesaikan kesulitan modal dalam melakukan pembangunan. Investasi asing sebagai prioritas utama dalam membantu dana yang dibutuhkan pemerataan pembangunan yang terjadi dalam krisis ekonomi. Sebab investasi asing sangat bermanfaat bagi pengguna modal, yeknologi, skill atau kemampuan mengelola dana ekonomi yang dimlikinya. Untuk itu pemerintah Indonesia mengharapkan investasi asing dapat keluar dari krisis yang melanda. Dengan penggunaan modal yang disalurkan cukup besar dianggap bisa membangun infrastruktur kedaerah lainnya dan kemerataan suatu wilayah harus seimbang. ${ }^{19}$

\footnotetext{
${ }^{16}$ Windhu Putra, Op.Cit, hlm 136-137

${ }^{17}$ AG Kartasoeputra dan Setiady. (1995). Manajemen Penanaman Modal Asing. Jakarta: PT.Bina Aksara, hlm 48

${ }^{18}$ Fery Dona, Peran Penanaman Modal Asing (PMA) dalam Pembangunan Ekonomi di Era Otonomi Daerah, Jurnal Ilmu Syari'ah dan Hukum Vol. 2, Nomor 1, Januari-Juni 2017

${ }^{19}$ Henry Faizal Noor. (2014). Investasi, Pengelolaan Keuangan dan Pengembangan Ekonomi Rakyat, Penerbit Mitra Wacana Media, Jakarta, hlm. 49
} 
Kehadiran investasi asing di Indonesia memberikan keuntungan dan kepeduliannya dalam perekonomian dan mengatasi mengatasi masalah yang terjadi. Disamping itu juga menciptakan lapangan kerja bagi masyarakat untuk memberikan peluang bagi kalangan investor menanamkan modalnya ke Indonesia. Oleh sebab itu, pemerintah harus siap menghadapi investasi asing yang datang untuk menanamkan modalnya demi kemajuan bangsa dan bernegara. Lapangan kerja sangat penting bagi masyarakat berkat adanya investasi asing di wilayah di Indonesia. Sebagai dasar hukum yang dijalani harus melakukan pengawasan dan tindakan terhadap masuknya investasi asing yang melakukan perbuatan penyimpangan kegiatan usahanya. Secara tegas regulasi sudah melakukan aturan hukum dan memberikan perlindungan hukum. Atas aturan tersebut penyediaan lapangan kerja di sektor lain khususnya mendatangkan investasi asing untuk membuka usahanya di wilayah Indonesia yang harus memperkerjakan orang Indonesia. Ketenagakerjaan yang dimiliki oleh investasi asing membutuhkan tenagakerja yang terampil dan efisien. ${ }^{20}$

Pemerintah memberikan peluang bagi berinvestasi asing ke wilayah Indonesia, agar mensejahteraan pembangunan khususnya bidang ekonomi. Ketetapan sudah diatur sedemikian rupa agar investasi asing bisa memberikan kesempatannya untuk kegiatan usahanya di Indonesia. Menjalin kerjasa sama secara global dan bilateral mengingat investasi asing memberikan dampak positif luar biasa. Keunggulan yang dimiliki tenaga kerja asing membutuhkan sumber daya manusia yang handal agar dapat memperkerjakan secara tepat. Untuk itu pemerintah tidak melakukan diskriminasi dan hambatan disaat investasi asing hadir dalam memperkerjakan proyek pembangunan infrastruktur. ${ }^{21}$

Sebagai investasi asing memainkan perannya dalam meningkatkan pertumbuhan ekonomi sebuah negara tetap maju dan memanfaatkan hasil-hasil alam dan berbagai sektor secara produktif agar bisa menggunakan seutuhnya. Sebab investasi asing membutuhkan lokasi yang dinamis dalam menjalankan roda pembangunan yang mantap. Disamping itu, investasi asing melakukan secara selektif dan terarah agar dampak yang terjadi bisa terselesaikan. Dengan demikian kehadiran investasi asing dapat mewujudkan proses pembangunan yang sedang dijalankan dan meningkatkan taraf pendapatan yang seimbang dan diatur berdasarkan undangundang maupun aturan perusahaan secara tepat dan adil. Pembangunan ekonomi sangat dibutuhkan bila investasi asing melakukan perubahan agar tetap terjaga hubungan dan bilateral yang baik.22

Penulis menyimpulkan bahwa kehadiran investor asing dapat terwujud jika pendapatan riil meningkat lebih tajam, agar terarah dan terukur demi keseimbangan ekonomi yang ada. Berikutnya memberikan manfaat bagi penggunaan teknologi dan penemuan baru, apalagi saat ini menghadapi era revolusi industri. Ada beberapa hal menjadi kelemahan kehadiran investasi asing diantaranya kurangnya pengawasan oleh penegakan hukum terkait lapangan kerja asing yang berlebihan, kurang tercapainya produk yang diekspor malahan sasaran kurang tepat akhirnya permintaan pasar menurun, padahal kegiatan usaha asing sudah diatur dalam UUPM dan peraturan lainnya. Untuk itu pemerintah mengambil sikap agar mengambil tindakan supaya tidak terjadi penyimpangan atau disalahgunakan dan dimanfaat di kalangan perusahaan asing agar menguntungan sebanyaknya tanpa memikirkan efek dan kerugian negara.

Investasi asing cukup memberikan pengaruh yang positif berupa upah karyawan meningkat berdasarkan bidang yang dikuasainya, perusahan asing lebih cepat menerima lapangan kerja dibandingkan perusahaan dalam negeri, membantu biaya pendidikan selama karyawan tetap, mengekspor lebih banyak dibandingkan perusahaan dalam negeri, inilah investasi asing

\footnotetext{
${ }^{20}$ Hulman Panjaitan dan Anner. (2008). Mangatur Sianipar, Hukum Penanaman Modal Asing, Jakarta: IND HILL Co, hlm 73

${ }^{21}$ Tatang Ary Gumanti.(2011). Manajemen Investasi : Konsep, Teori dan Aplikasi, Jakarta: Mitra Wacana Media, hlm 11

${ }^{22}$ Abdul Manan.(2014). Peranan Hukum Dalam Pembangunan Ekonomi. Jakarta: Kencana, hlm 144-145
} 
mengambil keuntungan tetapi bisa memulihkan dampak yang terjadi. ${ }^{23}$ berikutnya pengaruh negatifnya menimbulkan sengketa. Setiap perusahaan pasti ada permasalahan tetapi tidak juga diselesaikan tetap terjadi sengketa dengan mengajukan pengadilan. Agar tidak berkepanjangan masalah yang terjadi harus ditetapkan dengan mengambil putusan.

\section{Dampak Kehadiran Investasi Asing Terhadap Pertumbuhan Ekonomi di Indonesia}

Sejak kehadiran investasi asing nasional sudah mempunyai aturan hukum berupa Undangundang Penanaman Modal dalam Negeri dalam pelaksanaannya terus mengalami perubahan. Tentu saja sasaran pemerintah untuk menjaga perkembangan ekonomi selama empat persen pertahunnya tidak mudah tercapai bila bantuan penanaman modal disalurkan menjadi naik. Sebab, rendahnya tabungan domestik bruto nasional dalam pembangunan daerah akan menjadi dampak bagi masyarakat. Untuk itu pemerintah berkomitmen melakukan kebijaksanaan regulasi dalam masalah tabungan nasional tersebut, agar tidak terjadi penurunan tabungan nasional.

Peran investasi asing dalam melakukan dana modalnya untuk dukungan pembangunan, semestinya tabungan nasional bisa membantu kekurangan yang terjadi. Sebagai tambahan modal agar tabungan nasional bisa terlaksana dan menjadi prioritas utama dalam pertumbuhan ekonomi. Pemerintah mengambil langkah agar tabungan nasional tidak terlepas dari penurunan, tidak mudah tabungan menjadi meningkat harus ada dukungan setiap sektor agar bisa terjaga dengan baik. $^{24}$

Kegiatan investasi asing menjadi salah satu target dalam rangka membantu mendanai proyek pembangunan nasional, pada akhirnya akan memberikan sumbangan ekonomu nasional. Ketetapan pembangunan ekonomi nasional memberikan manfaat bagi investasi asing. Hal ini sudah jelas bahwa sumber dana dari investasi asing seluruhnya digunakan hanya pembangunan nasional dan dipakai dalam jangka waktu yang sudah ditentukan. Sumber dana yang disalurkan akan menjadi sarana dan prasarana dalam kegiatan pembangunan.

Investasi asing mendukung kegiatan pembangunan dalam rangka menunjang kebutuhan dan konsisten dalam regulasi sehingga memberikan jaminan kepada investor dan keamanannya. Oleh karena itu layanan dan prosedur sudah ada aturan yang dilakukan oleh pemerintah, tinggal saja investor melengkapi perijinan dalam melakukan investasi asing. Upaya pemerintah tersebut agar tidak terjadinya penyimpangan dan disalahgunakan sebagai kegiatan usahanya. Setiap investor yang masuk minta ijin setiap daerah apabila investasi di lokasi yang diinginkan bisa terwujud.

Misalnya jumlah data utang luar negeri di Indonesia menjadi peningkatan hal ini disebabkan karena adanya debt service selalu meningkat tiga empat persen, hal ini menunjukkan bahwa defisit transaksi berjalan dari pendapatan domestik bruto mengalami penurunan menjadi empat persen. Oleh karena itu, dukungan investasi asing atas peningkatan utang yang terlalu besar, maka bisa menutupi atas masalah yang terjadi. Pemerintah dan swasta bisa mengatasi problem terjadi atas bantuan investasi asing tersebut. Melihat keadaan seperti ini bisa menjadi proriatas utama dalam membangun ekonomi tetap stabil. Investasi asing mampu memberikan pembiayaan pemerintah yang sedang terjadi dan bisa bangkit kembali dengan membiayai utang luar negeri.

Semua sektor bisa diandalkan dan dibutuhkan sebagai keuntungan yang dijanjikan oleh investasi asing. Keuntungan yang diperoleh bisa membiayai dan menstabilkan ekonomi yang sedang terpuruk. Oleh sebab itu investasi asing memastikan bisa membangun kembali keadaan

\footnotetext{
${ }^{23}$ Salim HS dan Budi Sutrisno, Op.Cit, hlm 84

${ }^{24}$ Hendrik Budi Untung.(2010). Hukum Investasi. Jakarta: Sinar Grafika, hlm 49
} 
yang terjadi, dan menanamkan modalnya untuk mempercepat pembangunan di Indonesia. Mengingat keadaan tersebut bisa teratasi dengan adanya dukungan dan dorongan dalam investasi asing membiayai perekonomian nasional. ${ }^{25}$

Adapun dampak investasi asing ke Indonesia berupa kurangnya keamanan dan kepastian hukum bagi investasi asing, untuk itu pemerintah mengambil langkah agar tidak menimbulkan keresahan dalam menanamakan modalnya ke Indonesia, sedangkan pengaturan tidak konsisten selalu ada celah yang membiarkan bisa masuk dan bebas, lahan sekitar wilayah belum memadai, pelayanan dan fasilitas publik tidak merata akibat permainan oknum, pajak dan insentif nonfiskal lain yang tidak mendukung investasi; dan lapangan kerja tidak memiliki keterampil yang menunjang dan belum memadai. Seharusnya berbagai ketersediaan sangat dibutuhkan oleh investasi asing agar tidak terjadi kelemahan dalam membangun roda perekonomian bangsa dan negara. ${ }^{26}$

Padahal sudah dikeluarkannya Kepres tentang penyelenggara penanaman modal dalam satu atap, tetapi yang terjadi hanya kerancuan dan birokrasi perijinan semata. Bahkan berlakunya otonomi daerah sudah pernah terjadi, semakin banyak peraturan daerah yang menutup jalannya investasi asing. Peraturan daerah yang membuat terhambat investasi asing untuk melakukan penanaman modalnya ke suatu wilayah yang ditujunya. Peraturan tersebut sangat bertentang tetapi akhirnya meminta biaya lebih tinggi dari investasi asing. Mau tidak mau investasi asing mengeluarkan dananya untuk biaya tinggi kepada pemerintah setempat. Itulah menjadi problem dalam mengelola investasi asing yang mendukung mempercepat pembangunan ekonomi. Tetapi pada akhirnya investasi asing tidak mau lagi berinvestasi asing karena rasa aman dan kepastian hukum belum bisa memberikan perlindungan kepada investor.

Kehadiran investasi asing mengalami kerugian atas pertumbuhan ekonomi, maka permasalahannya adalah :

1) pemerintah sering berbaik hatikepadakebijakan yang diambil tetapi hanya menguntungkan bagi investasi asing, misalnya pembebasan pajak hanya memberi waktu belum ditentukan, tetapi pemerintah mengandung resikonya. Pemerintah selalu membantu investasi asing agar dipermudah dan berjalan dengan lancar tidak ada kendala yang didapat, cukup hanya memberikan biaya kepada pemerintah agar investasi asing dapat mudah masuk.

2) Adanya persaingan antara perusahaan industri dalam negeri dengan perusahan industri luar negeri cukup ketat. Apabila dibebankan biaya penyesuaian ditanggung oleh perusahaan industri lokal terlalu tinggi, dibandingkan biaya penyesuaian perusahan investasi asing tidak terlalu tinggi, akibatnya ketidakseragaman tersebut menjadi problem cukup besar. Karenatumpang tindihnyanya biaya yang dikeluarkan menjadi masalah. Ketidakmampuan membayarbebanpenyesuaianterlaluitinggidiperusahanlokalmenjadiproblem, sedangkan perusahaan industri investasi asing sudah mengatur oleh pemerintah.

3) Ketergantungan investasi asing menjadi problem, karena kehadiran investasi asing melahirkan penjajahan ekonomi. Setiap ada dana yang disalurkan membiayai segala bidang, dan pemerintah tidak mau mengambil resiko, hanya berkepentingan pribadi saja. Seharusnya pemerintah menjaga konsekuensi dalam memajukan suatu wilayah bukan saja ketergantungan para investasi asing saja. ${ }^{27}$

4) Perbedaan perijinan menjadi problem penting karena biaya yang ditimbulkan ketidakseimbangan antara investasi asing dengan lokal. Kepengurusan perijinan investasi asing dipermudah sedangkan lokal tidak mudah mesti menjalani proses yang berlaku. Banyak perijinan yang tidak resmi oleh investasi asing hanya meminta bantuan seseorang/

\footnotetext{
${ }^{25}$ Aminuddin Umar, Op.Cit, hlm 188

${ }^{26}$ Hilma Meilani, Hambatan Dalam Meningkatkan Investasi Asing Di Indonesia Dan Solusinya, Bidang Ekonomi dan Kebijakan Publik INFO Singkat : Kajian Sigkat Terhadap Isu Aktual dan Strategis Vol. XI, No.19/I/Puslit/Oktober/2019

${ }^{27}$ Ibid., hlm 192
} 
kalangan pejabat hanya kepentingan sendiri. Terbukanya jalan investasi asing di Indonesia begitu mudah hanya memberikan biaya yang rendah sedangkan investasi lokal biaya tinggi. Tentunya akan mempengaruhi iklim investasi lokal yang dikelolanya terhambat adanya biaya tinggi. ${ }^{28}$

Aturan yang dibuat pemerintah sangat mempengaruhi pelaksanan investasi, sehingga perusahaan sangat ketergantungan akan masuknya investor. Perusahaan asing yang dirikan menjadi keuntungan sendiri bagi pemerintah, karena adanya biaya dipungut dan menghasilkan keuntungan. ${ }^{29}$ Investasi asing selalu membebani masalah biaya tambahan agar dipermudahkan jalan usaha yang dibuatnya. Persoalan ini tidak adanya koordinasi yang baik antara pemerintah pusat dan daerah sehingga terjadi biaya tersendiri, ${ }^{30}$ sehingga problem ini membiarkan kalangan pejabat maupun oknum melakukan biaya kepada investasi asing. Rasa aman investasi asing masih terkendala dan belum menjamin kepastian hukum hanya menguntungkan diri sendiri. Tidak ada kejelasan peraturan daerah dalam persoalan penyelenggara investasi asing yang berakibat ketidakefisienan pengurusan perijinan tersebut.

Ketidaktahuan pemerintah pusat dengan daerah berakibat tumpang tindih dan ketidakjelasan manfaat biaya yang disalurkan. Oleh karena itu, pemerintah berkoordinasi satu sama lainnya agar tidak terjadinya penyelewenangan dana yang dilakukan oleh investasi asing. sering kali para oknum memberikan kesempatan untuk mengambil keuntungan kepada investasi asing, tetapi pemerintah tidak memberikan sanksi hanya berupa teguran. Seharusnya ada pengawasan yang dilakukan agar tidak terjadi problem di hari kedepannya. Pemerintah berwenang dan tindakan atas pejabat dan oknum yang nakal melakukan biaya tinggi kepada investasi asing, undang-undang sudah mengaturnya tetapi tidak dijalankan semestiya.

Penulis menyimpulkan bahwa UUPM sudah menjelaskan ketentuan yang diatur sudah pahami dan memberikan perlindungan investasi asing. UUPM diharapkan bisa membantu investasi asing menyelesaikan masalah hukum, karena banyak investasi asing yang memanfaatkan keuntungan semata di kalangan pejabat dan oknum. Tindakan tersebut harus andil dan memberikan kepastian hukum agar investasi asing merasa aman dalam melakukan kegiatan usahanya. Kehadiran investasi asing sangat berpengaruh pada persoalan lahan tanah, karena lahan membutuhkan biaya dan perluasan agar bisa berkembang. Problem sengketa tanah yang menjadi penghambat karena ketidaksesuai harga yang ditetapkan, sehingga terjadi pembebasan tanah. Banyak perusahaan asing batalkan karena problem sengketa tanah, karena belum menyelesaikan masalah yang terjadi. Untuk itu persoalan perijinan menjadi kelemahan bagi investasi asing, padahal UUPM sudah mengatur sepenuhnya. Semakin mahalnya tanah yang dijanjikan membuat investasi asing membatalkan dan berisko keamanan bagi usaha investor. Ketidakefektifnya masalah yang terjadi menjadi risiko bagi pemerintah mengambil tindakan dan solusi agar memberi buka jalan investasi asing membangun usaha perusahaan industri wilayah di Indonesia.

\section{Upaya menarik Investasi asing dalam Mempercepat Pertumbuhan Ekonomi Nasional}

Pemerintah mengupayakan investasi asing demi kemajuan ekspor dan impor khususnya dalam negeri, kebijaksanaan yang dilakukan oleh pemerintah demi mendapatkan keuntungan dan memperioritas tempat perusahaan yang dituju brupa prasarana. Prasarana yang diberikan oleh pemerintah kepada investasi asing agar bisa menentukan tempat berdirinya perusahaan tersebut, agar lebih memajukan pertumbuhan bisnis menjadi handal dan efektif.

Kewajiban pemerintah memberikan keamanan bagi investasi asing agar tetap terjaga dan hubungan atas kerjasamanya dalam menanamkan modal ke Indonesia. Kepastian hukum sudah

\footnotetext{
${ }^{28}$ David Kairupan, Op.Cit, hlm 30

${ }^{29}$ Jonker Sihombing. (2019).Hukum Penananaman Modal di Indonesia. Bandung: Alumni, hlm 46

${ }^{30}$ Irham Fahmi.(2014). Studi Kelayakan Bisnis dan Keputusan Investasi. Jakarta: Mitra Wacana Media, hlm 8
} 
terjamin adanya tindakan dan perijinan sudah ditetapkan menurut regulasi yang ditentukan. Dengan adanya keamanan investasi asing akan memberikan kepastian hukum yang diatur atas kebijakan pemerintah kota maupun provinsi/daerah. ${ }^{31}$ Kepastian hukum sudah pasti investasi asing bisa memberikan dampak positif karena memiliki keamanan dan kemudahan perijinan. Untuk itu Indonesia sudah saatnya memberikan peluang masyarakat untuk ketersediaannya tenaga kerja terampil bagi investor asing dan mengembangkan keterampilan dan skill yang ada. Dengan demikian investasi asing bisa menumbuhkan ekonomi secara cepat maupun memajukan rakyat jadi maju kedepannya. ${ }^{32}$

Terjaminnya hubungan investasi asing dengan Indonesia tetap terjaga dan memberikan peluang bagi Indonesia untuk mengembangkan skill dan tenaga kerja terampil. kebijakan pemerintah tersebut sudah memberikan dampak positif bagi kalangan investor membuka peluang bagi kegiatan usahanya di Indonesia. Apabila perijinan sangat mudah dan tidak berbelit urusan izin tertentu, permasalahan yang terjadi dalam perijinan ini berbelit akan membawa dampak cukup besar, karena akses keamanan cukup susah. Oleh karena itu pemerintah melakukan upaya agar tidak seperti ini. untuk itu terpentingnya prasarana sebagai dukungan agar bisa masuk investor asing ke dalam negeri. ${ }^{33}$

Prsarana dan lokasi sudah dilakukan oleh pemerintah sudah efektif karena ada kehadiran investasi asing. Selain itu perijinan sangat fasilitas sangatlah penting bagi investasi asing karena memberikan kemudahan masuknya investor asing tersebut. ketersediaan tenaga kerja yang terampil akan menambah semangat masyarakat membawa perubahan era sekarang. Banyak perusahaan asing di Indonesia memiliki kinerja yang handal dan terampil karena adanya skill dan pengalamana yang ada. Apalagi saat ini kemajuan begitu pesat adanya investasi asing membawa tenologi baru dan mengembangkan produk yang handal.

Kehadiran investasi asing tersebut telah memberikan hubungan bilateral antar pemerintah dengan perusahaan swasta yang baik. Investasi asing juga meningkatkan kesejahteraan bagi daerah lokal maupun masyarakat sekitarnya karena bentuk perubahan begitu cepat, jangan sampai merusak lingkungan dan ekosistem SDA yang ada. Tercapainya perekonomian Indonesia karena dukungan investasi asing ke dalam negeri. ${ }^{34}$ Pemerintah sebagai perananya sebagai kemajuan perekonomian dan mensejahteraan rakyat kedepannya. Kemajuan saat ini ditingkatkan karena perkembangan kedepan membawa perubahan, maka pemerintah mengupayakan investasi asing bisa mempercepat pertumbuhan ekonom, diantaranya :

\section{a. Prasarana}

Pembangunan prasarana sangat penting bagi rakyat Indonesia. Kehadiran investasi membawa dampak positif dan tercapainya ekonomi di mata masyarakat. Prasarana salah satu aspek penting bagi kemajuan suatu daerah untuk mengembangan investasi asing. Ketersediaan lokasi dan fasilitas sangat mudah dan efektif melakukan penamaman modalnya ke Indonesia.

\section{b. Tenaga kerja}

Tenaga kerja sebagai prioritas utama dalam kemajuan ekonomi. Tanpa bekerja masyarakat tentunya tidak memperoleh pendapatan sesuai denga jenis pekerjaan yang diterimanya.

\footnotetext{
${ }^{31}$ Grandnaldo Yohanes Tindangen, Perlindungan Hukum Terhadap Investor Menurut Undang-Undang Nomor 25 Tahun 2007 Tentang Penanaman Modal, Jurnal Lex Administratum, Vol. IV/No. 2 July 2016

${ }^{32}$ Mochtar Kusumaatmadja, Investasi di Indonesia dalam Kaitannya dengan Pelaksanaan Perjanjian Hasil Putaran Uruguay, Jurnal Hukum Ius Quia Iustum Vol. 3 No.5 Oktober 1996

${ }^{33}$ Sri Handayani, Upaya Pemerintah Menarik Investor Asing dalam kegiatan Penanaman Modal, Jurnal Dinamika Hukum Vol.11 No.1 Januari 2011, hlm 70

${ }^{34}$ Hilma Meilani, Hambatan Dalam Meningkatkan Investasi Asing Di Indonesia Dan Solusinya, Bidang Ekonomi dan Kebijakan Publik INFO Singkat : Kajian Sigkat Terhadap Isu Aktual dan Strategis Vol. XI, No.19/I/Puslit/Oktober/2019
} 


\section{c. Perizinan}

Kemudahaan perijinan sangat diperlukan agar investasi asing biar masuk ke wilayah manapun, khususnya di Indonesia. Untuk itu pemerintah tidak memberikan kerumitan dalam proses perijinan agar bisa mendirikan perusaaan asing wilayah manapun.

\section{d. Biaya Insentif dari pemerintah}

Pemerintah mewajibkan memberikan insetif dan kemudahan akses hukum maupun lainnya agar tidak terjadi hambatan. Dukungan pemerintah dalam menarik investasi asing ke dalam negeri sebagai bantuan dan dukungan agar masyarakat mau memberikan peluangnya bagi pekerja.

\section{e. Jaminan hukum}

Jaminan hukum di investasi asing merasa aman dan terjaga. Disaat itu juga pemerintah memberikan jaminan bagi perusahaan asing yang ingin menanamkan modalnya.

\section{f. Kesejahteraan}

Seorang investasi asing hanya membawa kegiatan usahanya manapun yang terpenting pengalaman pekerjaan dan skill seadanya. Kesejahteraan rakyat di utamakan agar pertumbuhan ekonomi melaju naik. ${ }^{35}$

Penulis menyimpulkan bahwa upaya yang dicapai oleh pemerintah dengan pihak investasi asing keutuhan dan hubungan bilateral kerjasama yang baik. Selain itu, investasi asing menciptakan lapangan kerja dan memberikan kemajuan teknologi era sekarang. Apabila terwujudnya investasi asing yang kondusif akan melahirkan perubahan dalam perkembangan perekonomian secara baik dan utuh, oleh karena itu investasi asing harus menjadi prioritas utama akan menompang penanaman modal. Selain itu, pemerintah sudah menjamin memberikan kepastian hukum kepada investasi asing

\section{KESIMPULAN}

Peran Investasi asing terhadap percepatan pertumbuhan ekonomi di indonesia memberikan kontribusi yang nyata bagi perekonomian, perkembangan teknologi dan perbaikan infarstruktur selain itu juga menciptakan lapangan pekerjaan lebih cepat. Selain itu dengan adanya kegiatan investasi asing akan menghasilkan penerimaan Negara. Dampak kehadiran investasi asing terhadap pertumbuhan ekonomi di Indonesia berupa kurangnya keamanan dan kepastian hukum bagi investasi asing, untuk itu pemerintah mengambil langkah agar tidak menimbulkan keresahan dalam menanamakan modalnya ke Indonesia, sedangkan pengaturan tidak konsisten selalu ada celah yang membiarkan bisa masuk dan bebas, lahan sekitar wilayah belum memadai, pelayanan dan fasilitas publik tidak merata akibat permainan oknum, pajak dan insentif nonfiskal lain yang tidak mendukung investasi; dan lapangan kerja tidak memiliki keterampil yang menunjang dan belum memadai, ketersediaan sangat dibutuhkan oleh investasi asing agar tidak terjadi kelemahan dalam membangun roda perekonomian bangsa dan negara. Upaya menarik investasi asing dalam mempercepat pertumbuhan ekonomi nasional diantaranya Inftrastruktur, tenaga kerja terampil, kemudahan perizinan, insentif dari pemerintah, jaminan hukum dan kesejahteraan masyarakat. Pemerintah melakukan transparan dalam melakukan investasi asing, agar tidak dimanfaatkan dan keuntungan bagi kalangan pejabat maupun oknum. Disamping itu dipermudahkan perijinan bagi investasi asing yang

${ }^{35}$ Ida Bagus Rahmadi Supancana.(2006). Kerangka Hukum dan Kebijakan Investasi Langsung Di Indonesia. Bogor: Ghalia Indonesia, hlm. 98 
melakukan kegiatan usahanya, agar bisa bersaing berbagai produk yang dimilikinya, sehingga menjaga hubungan dan bilateral kedua negara tersebut. Untuk itu, UUPM telah melindungi bagi investasi asing yang ingin membuka usahanya ke Indonesia. Regulasi tersebut sangat tepat bila investasi asing membutuhkan perlindungan dan kepastian hukum. Dengan kehadiran investasi asing membawa dampak positif bagi kalangan perusahaan maupun semua sektor, dan meningkatkan pertumbuhan ekonomi yang stabil.

\section{DAFTAR PUSTAKA}

\section{Buku:}

Abdul Manan, Peranan Hukum Dalam Pembangunan Ekonomi, Penerbit Kencana, Jakarta, 2014

AG Kartasoeputra dan Setiady, Manajemen Penanaman Modal Asing, PT.Bina Aksara, Jakarta.1995

Amiruddin dan H. Zainal, Pengantar Metode Penelitian Hukum, Jakarta : Penerbit Rajawali Pers, 2013

Amiruddin Ilmar, Hukum Penanaman Modal di Indonesia, Penerbit Kencana, Jakarta, 2007

Ana Rokhmatussa"dyah dan Suratman, Hukum Investasi \& Pasar Modal, Penerbit Sinar Grafika, Jakarta, 2015

David Kairupan, Aspek Hukum Penanaman Modal Asing di Indonesia, Penerbit Kencana, Jakarta, 2013

Ediwarman, Metodologi Penelitian Hukum, PT Sofmedia, Medan, 2015

Hendrik Budi Untung, Hukum Investasi, Penerbit Sinar Grafika, , Jakarta, 2010

Henry Faizal Noor, Investasi, Pengelolaan Keuangan dan Pengembangan Ekonomi Rakyat, Penerbit Mitra Wacana Media, Jakarta, 2014

Hulman Panjaitan dan Anner Mangatur Sianipar, Hukum Penanaman Modal Asing, Penerbit IND HILL Co, Jakarta, 2008

Ida Bagus Rahmadi Supancana, Kerangka Hukum dan Kebijakan Investasi Langsung Di Indonesia, Penerbit Ghalia Indonesia, Bogor, 2006

Irham Fahmi, Studi Kelayakan Bisnis dan Keputusan Investasi, Penerbit Mitra Wacana Media, Jakarta, 2014

,Pengantar Perekonomian Indonesia: Teori, Konsep dan Realita, Penerbit Alfabeta, Bandung, 2018

Johnny W. Situmorang. Menguak Iklim Investasi Pasca Krisis. Penerbit Erlangga, Jakarta, 2011

Jonker Sihombing. Hukum Penananaman Modal di Indonesia. Penerbit Alumni, Bandung, 2019

P. Eko Prasetyo, Fundamental Makro Ekonomi, Penerbit Beta Offset, Yogyakarta, 2011

Salim HS dan Budi Sutrisno, Hukum Investasi di Indonesia, PT. Rajagrafindo Persada, Jakarta, 2008

Tatang Ary Gumanti, Manajemen Investasi : Konsep, Teori dan Aplikasi, Penerbit Mitra Wacana Media, Jakarta, 2011 
Windhu Putra, Perekonomian Indonesia, Penerbit Rajawali Pers, Depok, 2018

Zainuddin Ali, Metode Penelitian Hukum, Penerbit Sinar Grafika, Jakarta, 2014

\section{Undang-Undang:}

Undang-undang Nomor 25 Tahun 2007 tentang Penanaman Modal

\section{Jurnal :}

Agung Sudjati Winata, Perlindungan Investor Asing dalam Kegiatan Penanaman Modal Asing dan Implikasinya Terhadap Negara, Ajudikasi : Jurnal Ilmu Hukum, Vol. 2 No. 2. Desember 2018

Catherine Vania Suardhana, Perlindungan Hukum Terhadap Penanaman Modal Asing pada Sektor Perkebunan di Indonesia, Jurnal Hukum Prasada, Vol. 6, No. 1, Maret 2019

Fery Dona, Peran Penanaman Modal Asing (PMA) dalam Pembangunan Ekonomi di Era Otonomi Daerah, Jurnal Ilmu Syari'ah dan Hukum Vol. 2, Nomor 1, Januari-Juni 2017

Grandnaldo Yohanes Tindangen, Perlindungan Hukum Terhadap Investor Menurut UndangUndang Nomor 25 Tahun 2007 Tentang Penanaman Modal, Jurnal Lex Administratum, Vol. IV/No. 2 July 2016

Hilma Meilani, Hambatan Dalam Meningkatkan Investasi Asing Di Indonesia Dan Solusinya, Bidang Ekonomi dan Kebijakan Publik INFO Singkat : Kajian Sigkat Terhadap Isu Aktual dan Strategis Vol. XI, No.19/I/Puslit/ Oktober/2019

Mochtar Kusumaatmadja, Investasi di Indonesia dalam Kaitannya dengan Pelaksanaan Perjanjian Hasil Putaran Uruguay, Jurnal Hukum Ius Quia Iustum Vol. 3 No.5 Oktober 1996

Nanda Aisyah, Muhammad Ashri, Nurfaidah Said, Analisis Hukum Kebijakan Daftar Negatif Investasi Berdasarkan Peraturan Presiden Nomor 44 Tahun 2016 Terhadap Pengusaha Ritel Indonesia, Jurnal Nagari Law Review Volume 1 Nomor 2, April 2018.

ri Handayani, Upaya Pemerintah Menarik Investor Asing dalam kegiatan Penanaman Modal, Jurnal Dinamika Hukum Vol.11 No.1 Januari 2011 